\title{
Toward alternative food systems development: Exploring limitations and research opportunities
}

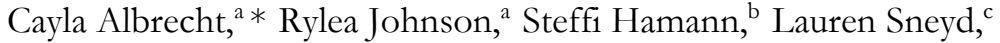 \\ Lisa Ohberg, ${ }^{,}$and Michael CoDyre ${ }^{\mathrm{d}}$ \\ University of Guelph
}

\begin{abstract}
Submitted June 19, 2013 / Revised August 27, 2013 / Published online September 3, 2013
Citation: Albrecht, C., Johnson, R., Hamann, S., Sneyd, L., Ohberg, L., \& CoDye, M. (2013). Toward alternative food systems development: Exploring limitations and research opportunities. Journal of Agriculture, Food Systems, and Community Development, 3(4), 151-159. http://dx.doi.org/10.5304/jafscd.2013.034.019

Copyright (C) 2013 by New Leaf Associates, Inc.
\end{abstract}

\begin{abstract}
In recent years, interest in alternative food systems (AFS) has grown both in the popular imagination and in the academic literature. The literature is rife with justifications (or hopes) for the continued and necessary expansion of AFS in the face of unsustainable conventional food provisioning. Within the next five years it will be important to determine how to make alternatives more stable in order for them to play a more prominent role in battling the food insecurity and other social and

a Masters candidate, Department of Geography, University of Guelph

b Doctoral student, Department of Political Science and International Development Studies, University of Guelph

${ }^{c}$ Doctoral candidate, Department of Geography and International Development Studies, University of Guelph

d Masters degree, Department of Geography, University of Guelph

* Corresponding author: Cayla Albrecht, Department of Geography, University of Guelph, Guelph, Ontario N1G 2W1 Canada; +1-519-824-4120 ext. 56719; cayla@,uoguelph.ca
\end{abstract}

economic challenges equated with agro-industrial foods. The goal of this commentary is to demonstrate some highly context-specific challenges and possible research trajectories in both the global South and the global North. We argue that in the global South more robust data collection can strengthen local food systems and traditional foods research, while in the global North, food skills and food literacy research may be important for scaling up and making alternative food systems more stable without compromising important social and economic ideals.

\section{Keywords}

alternative food systems, farm labor, food security, food skills, local foods, producer-consumer relationships, scale, traditional foods

\section{Introduction}

"Alternative" food systems (AFS) are often conceptualized in opposition to "conventional" global agro-industrial foods (Qazi \& Selfa, 2005). They are assumed to provide higher quality food (Ilbery 
\& Kneafsey, 2000), use more ecological agricultural practices (Morris \& Kirwan, 2011), and foster more equitable labor relations (Born \& Purcell, 2006). While some scholars have described "alternative" agriculture as "post-productivist" (Ilbery \& Bowler, 1998) or focused on "quality" over "quantity"

(Stock \& Carolan, 2012), many agree that we must move beyond the dichotomy of conventional vs. alternative conceptions of food provisioning because such simple distinctions are unhelpful and limiting (Evans, Morris, \& Winter, 2002; Friedmann, 2007; Maxey, 2006; Mount, 2012; Sonnino \& Marsden, 2006). The challenge now is to understand how AFS can in some sense disrupt this dichotomy and become more stable food sources capable of providing both "quantity" (more food for more people), and "quality" (social, economic, health, and environmental benefits) (Jaffe \& Howard, 2010; Jarosz, 2008; Milestad, Bartel-Kratochvil, Leitner, \& Axmann, 2010).

To identify new research areas for improving the stability of AFS, we reviewed literature published since the early 2000s, focusing on keyword clusters such as food security, alternative agriculture, alternative food networks, traditional foods, agricultural development, and local foods. Given the inherent volume of this endeavor, we divided the review among six contributors from backgrounds in political science, international development studies, and geography. To ensure consistency across the review we met throughout the process to present preliminary results and shared information to compare emerging themes. To identify core tensions in the literature we drew on a qualitative "thematic analysis" (Bryman, 2012) of our chosen body of work.

Against this backdrop, the goal of this paper is to demonstrate that making AFS a more stable food source is highly context-specific and takes on a different character in the global South and the global North, requiring different research trajectories. To accomplish this goal, we organized our commentary into two main sections. The first section addresses key tensions and identifies possible research avenues in regard to strengthening local food systems and traditional foods research in the global South through more robust data collection. The second section addresses key tensions and identifies possible research avenues in regard to scaling up and making AFS more stable in the global North without compromising important social and economic goals.

\section{Key Tensions in the Literature: Global South} Coincident with an ongoing trend of increasingly cheaper food available on global markets (Timmer, 2010), the number of chronically malnourished people had dropped since the 1970s despite a growing world population (Food and Agriculture Organization of the United Nations [FAO], 2013). However, these positive trends reversed in 2007 with the global economic downturn. As food prices spiraled upward in 2007-2008 and again in 2009-2010, food riots erupted as undernourished people across world regions were exposed to food price shocks (Sneyd, Legwegoh, \& Fraser, 2013). According to the FAO, the countries most exposed to the crises were food-importing nations located in sub-Saharan Africa (FAO, 2011) and countries dealing with the worst impacts of climate change, such as recurrent droughts in arid and semi-arid (ASAL) regions (Inter-Agency Standing Committee [IASC], 2009). The impact of the food crisis on poor urban households in sub-Saharan Africa has been profound (Swan, Hadley, \& Cichon, 2010). These households have had to adopt damaging coping strategies such as "spending a greater share of income on food, buying lower cost items, reducing the quality and diversity of food," and perhaps most damaging, "eating less and going hungry” (Hossain \& Ebyen, 2009, p. 11). The possibility of irreversible damage to a country's productive capabilities, as well as the "obvious human suffering, following the fall of food consumption below a certain minimum need," emphasizes the call to seriously address food security issues (Chang, 2009, p. 482).

The dominant narrative for addressing food security in the developing world rests on the assumption that by increasing trade, foreign exchange will grow and countries will be able to "access the bounty of global food markets" (Weis, 2011, p. 2), thus bringing in lower prices and more stable food supplies (Rosset, 2008; Weis, 2011). However, the promotion of export-oriented, capital-intensive agriculture by wealthy countries in 
order to "maximize foreign exchange earnings" (Weis, 2011, p. 2) has contributed to the transformation of the agricultural sector of African economies (McMichael, 2009). Africa's dependence on the global market for food security erodes selfsufficiency and national sovereignty (Rosset, 2008). Past policies such as debt and structural adjustment programs, combined with trade liberalization, have reduced the state's role in agriculture, further contributing to food insecurity and difficulties for farmers (Crush \& Fayne, 2011).

The food crises of the recent past clearly demonstrate that this type of "export oriented," "free market" approach may no longer be viable, as it has been found to erode the viability of farmers' livelihoods across the globe, especially in sub-Saharan Africa (Cooksey, 2011; Wittman, Desmarais, \& Wiebe, 2010). A new approach to food security is needed, but as the International Food Policy Research Institute (IFPI) points out, "a strong evidence base for an effective development strategy in the [Sub-Saharan] region is missing because the scientific analysis of ASAL regions is limited by poor data, limited policy experimentation, lack of scale, and lack of integration." (Headey, 2011, p. 1).

\section{Research Priorities: Global South}

While complex research efforts have been undertaken to assess the scope and impacts of AFS in the global North (e.g., Bean Smith \& Sharp, 2008; Conner, Becot, Hoffer, Kahler, Sawyer, \& Berlin, 2013; Peters, Bills, Lembo, Wilkins, \& Fick, 2009), our review of the literature suggests that knowledge gaps in this field persist with regard to the global South. In recent years, household conditions in particularly vulnerable groups have been examined in numerous isolated studies (e.g., Hadley, Linzer, Belachew, Mariam, Tessema, \& Lindstrom, 2011; Oluoko-Odingo, 2011). Research agendas should now seek to assess the scope and impact of AFS in a more comprehensive way in order to help specify their potential to contribute to improving food security in vulnerable households. Focusing on the linkages between local-scale food provisioning and food security is one way to promote AFS development as a possible approach to food security research in the global South.
National food balances (import-export) guide policies on trade, aid, and the domestic and international declaration of food crises (FAO 2001). Notably absent from food balance sheets at present is the contribution made by traditional foods, local foods, and foods that are not commonly traded internationally (Bharucha \& Pretty, 2010; Chang, 2009; FAO, 2001). Although modern agricultural specialization has resulted in a global homogenization of diets (Grivetti \& Ogle, 2000), a substantial number of native species of crops and livestock as well as native wild plants and animals are consumed by households and often make their way into local food baskets. These types of understudied foods tend to be overlooked in trade or aid policies, as well as in the academic literature.

With the routine underestimation of nonstaple foods "comes the danger of neglecting the provisioning ecosystems and supportive local knowledge systems that sustain these food chains" (Bharucha \& Pretty, 2010, p. 2913). For example, the concept of the "orphan crop" - neglected or underutilized foods that are regionally important but not traded around the world, including tubers, sorghum, and millet (Naylor, Falcon, Goodman, Jahn, Sengooba, Tefera, \& Nelson, 2004) - are very good for food security under climate change conditions, but are more or less ignored by mainstream food security work, which focuses on wheat, rice, and corn instead (see special issue of Africa Technology Development Journal, 2009). Therefore, we prioritize the need to understand the impacts of the global food crises on food choices, how local diets are changing and incorporating noncommodity, "orphan" crops, and households' experiences of food security and health.

Within the next five years, more data need to be generated about food security and the role of traditional food/AFS in the global South (Headey, 2011; Moseley, Carney, \& Becker, 2010). This will allow for adequate planning and implementation of effective development strategies. Researchers should also include the implementation of complex baseline surveys, particularly in urban households that are vulnerable to food insecurity in various regions of the global South (Crush \& Frayne, 2011; Legwegoh \& Hovorka, 2013). More large-scale research initiatives - such as the African Food 
Security Urban Network (AFSUN) (see Crush \& Frayne, 2011) - need to be undertaken throughout the developing world that involve universities, nongovernmental organizations, and government actors. Expanding such comprehensive research initiatives to other geographical regions would allow data to be analyzed and compared at local, regional, and international levels.

\section{Key Tensions in the Literature: Global North} In the global North, we focus on two interconnected challenges to AFS development. The first challenge is that despite social, economic, health, and environmental goals associated with AFS and the "local" scale (Born \& Purcell, 2006) there is limited empirical research to confirm their achievement. The second is that even if or when AFS can be said to achieve such goals, the practical ability of AFS to expand is unclear.

One of the primary goals of many AFS is to foster a renegotiated relationship between individual producers and consumers of food (Ilbery, Morris, Buller, Maye, \& Kneafsey, 2005; Sage, 2003). Geographically close producer-consumer interactions along with shorter food supply chains are seen as underpinning the structure and value of alternative food networks (Renting, Marsden, \& Banks, 2003; Watts, Ilbery, \& Maye, 2005) and local food initiatives (Hinrichs, 2003; Holloway \& Kneafsey, 2004; Holloway, Kneafsey, Venn, Cox, Dowler, \& Tuomainen, 2007; Venn, Kneafsey, Holloway, Cox, Dowler, \& Tuomainen, 2006). Decreasing geographical distance is assumed to achieve some sort of reconnection where both parties feel satisfied and share mutual interests (Dupuis \& Goodman, 2005; Ilbery et al., 2005; Sage, 2003). However, despite geographical proximity, scholars have begun to draw attention to disparities between consumer and producer understandings within AFS and local food systems (Hinrichs, 2003). While consumer interests and/or motivations might be based on "symbolic" (Guthman, 2002) or "subjective experiential" values (Miele, 2006; Smithers \& Joseph, 2010) associated with alternative foods, producer interests and/or motivations are predominantly based on material production costs and livelihood concerns (Guthman, 2002). Thus, although pro- ducers and consumers might be brought closer together geographically in alternative or local food systems, they might not necessarily share goals, interests, and values about food and food systems.

A second important goal embedded within AFS is the achievement of more equitable labor relations (Born \& Purcell, 2006) in comparison to the industrial food system's exploitation of human workers. Producers involved in alternative agriculture and AFS are often thought of as enlightened and conscientious small-scale farmers (Smithers, Lamarche, \& Joseph, 2008) committed to social, environmental, and economic justice. While many AFS do intend to create more equitable production relations than the industrial food system creates, the seasonal and unskilled nature of farm work paired with economic constraints and the infamous "price-cost squeeze" (Weis, 2007) create incentives for farm operators to populate their labor force with vulnerable workers.

In North America, much alternative agricultural production depends on migrant labor, particularly where crops are labor-intensive to plant or harvest, including southern Ontario (Barndt, 2008) and California (Brown \& Getz, 2008). Underpaid, temporary farm internship programs are also a vital source of labor for many farms in Ontario (Knezvic, Landman, Blay-Palmer, \& Nelson, 2013). Preliminary research has noted that many enterprises specializing in local or direct marketing and/or ecological production, draw heavily from volunteer labor programs such as WWOOFing (World Wide Opportunities on Organic Farms), as well as family labor, as they cannot afford to pay minimum wage prices (Knezvic et al., 2013; Ohberg, 2012). The reliance of many alternative food enterprises on migrant workers, interns, volunteers, or self-exploitative and/or family labor suggests that ideals of social and economic justice in alternative food systems are not easily achieved and also suggests that if equitable labor is not possible in many AFS, then the way in which we value food and food systems is problematic.

\section{Research Priorities: Global North}

Significant research has been devoted to identifying broad ideological goals surrounding AFS. The literature has also begun to point out that these 
goals are not always met. Important research priorities, then, are to understand why certain economic or social goals are not always achieved in AFS, to provide potential solutions to meeting these goals, and to move toward a "scaling-up" of AFS. Food skills and food literacy represent one possible avenue for understanding some of the challenges and potential solutions for AFS development.

Food skills and food literacy research are most frequently connected to health and nutrition studies. There is some evidence to suggest that improving food skills may have a small but positive effect on food choices and food preparation (Wrieden, Anderson, Longbottom, Valentine, Stead, Caraher, \& Dowler, 2007) and a significant improvement in the ability to estimate portion sizes (Ayala, 2006). One study in Europe found that those with higher food skills were likely to eat more vegetables and less processed convenience foods (Hartmann, Dohle, \& Siegrist, 2013), while a comparative study found that Iceland, where food skills are taught from the age of six, had better health standards than Canada, where food skills are not entrenched in education (Stitt, 1996).

Some scholars also have suggested that food skills have significant impact on societal conceptions of food and food value. The shift over the past century from preparing meals primarily from raw ingredients to consuming pre-prepared convenience foods requiring little or no effort (EnglerStringer, 2010; Shapiro, 2004) is inextricably tied to the industrialization of the food system. The convenience, variety, and overall cheapness of industrial foods have fundamentally changed what people expect from and how they value food (Hinrichs, 2000; Miele, 2006; Mount, 2012; Smithers et al., 2008). Not only has the industrialization of food arguably contributed to a significant food "deskilling" of developed world consumers, but also to a "de-valuing" of food in general. It is perhaps the "de-skilling" and "de-valuing "processes that present the largest underlying obstacles for AFS development. This avenue of research however, is overlooked in connection to challenges in AFS development, such as farm profitability and labor relations, or producer-consumer understandings and valuing of food and food systems.
In the next five years, it will be important to examine the social-justice implications of the precarious labor force upon which alternative agriculture in North America often relies; gain greater understanding into the potentially conflicting interests between producers and consumers in AFS; and understand how increased food skills relate to understanding and valuing of food and AFS. This research will paint a clearer picture of why social and economic goals are not always met in alternative food provisioning and help determine what role, if any, food skills and literacy can play in improving the economy and potential of AFS.

In addition to the challenges of AFS in the developed world meeting broad ideological goals, the question of how to make AFS more widespread is important for future research. Because most of the literature has been focused on case studies that identify and explore alternatives operating at a limited scale (Campbell, 2009; Chiffoleau, 2009; Feenstra, 2002; Hinrichs, 2000; Ostrom, 2009), there is room to explore how AFS can grow, become more stable, and operate at a larger scale. The call for scaling up is complementary to and hinges on gaining greater understanding of the above-mentioned challenges. Research in the next five years should focus on understanding current infrastructure, networks, and distribution options for alternative food systems, as well as the ability for some alternatives to make use of more conventional food system networks.

\section{Conclusion}

In the past decade, the study of alternative food systems has gained a great deal of momentum. Much research in the developed world revolves around determining what various AFS look like and defining and outlining their different qualities. AFS study is less robust in the developing world, but research into local and traditional foods and food security is growing. In both contexts, determining how to make alternatives more stable in order for them to play a more prominent role in battling food insecurity and other social and economic challenges related to agro-industrial foods is important for the next five years of research. The following table summarizes some of the key tensions this 
commentary identified in the existing literature, as well as future research priorities to help in the development of alternative food systems in both the global South and the global North.

\section{Figure 1. Summary of Key Research Themes and Priorities}

\begin{tabular}{|c|c|c|c|}
\hline & Key Themes in Literature & Key References & Research Priorities \\
\hline Global South & $\begin{array}{l}\text { 2007/08 global economic } \\
\text { downturn and increasing } \\
\text { food prices } \\
\text { - Export oriented agriculture, } \\
\text { commodity crops }\end{array}$ & $\begin{array}{l}\text { - FAO, 2011, 2013; } \\
\text { - McMichael, 2009; Rosset, } \\
\text { 2009; Weis, } 2011\end{array}$ & $\begin{array}{l}\text { - Local scale food provisioning } \\
\text { and traditional foods } \\
\text { - Changing diets and 'orphan' } \\
\text { crops } \\
\text { - Complex data collection }\end{array}$ \\
\hline Global North & $\begin{array}{l}\text { - Social and economic } \\
\text { ideological goals of AFS } \\
\text { (reconnection and equitable } \\
\text { labor relations) } \\
\text { - Small-scale case studies }\end{array}$ & $\begin{array}{l}\text { - Ilbery et al., 2005; Renting } \\
\text { et al., 2003; Sage, 2003; } \\
\text { - Feenstra, 2002; Hinrichs, } \\
\text { 2000; Ostrom, } 2009\end{array}$ & $\begin{array}{l}\text { - } \text { Food skills and literacy } \\
\text { - Social justice, labor relations, } \\
\text { producer-consumer interests } \\
\text { - Infrastructure and/or } \\
\text { networks }\end{array}$ \\
\hline
\end{tabular}

\section{References}

Africa Technology Development Journal. (2009). Special issue African orphan crops: Their significance and prospects for improvements. Africa Technology Development Journal, 6 (3/4). Retrieved from http://www.atdforum.org/journal/pdf/ATDFJournal-2009-Issue3,4-Orphan Crops-May2010.pdf

Ayala, G. X. (2006). An experimental evaluation of a group- versus computer-based intervention to improve food portion size estimation skills. Health Education Research, 21(1), 133-145. http://dx.doi.org/10.1093/her/cyh049

Barndt, D. (2008). Tangled routes: Women, work, and globalization on the tomato trail (2nd ed). Lanham, Maryland: Rowman \& Littlefield Publishers.

Bean Smith, M., \& Sharp, J. S. (2008). A current and retrospective look at local food consumption and support among Obioans (Social Responsibility Initiative Topical Report 08-02). Retrieved from http://ohiosurvey.osu.edu/publications/food.html

Bharucha, Z., \& Pretty, J. (2010). The roles and values of wild foods in agricultural systems. Philosophical Transactions of the Royal Society B: Biological Sciences, 365(1554), 2913-2926.

http://dx.doi.org/10.1098/rstb.2010.0123

Born, B., \& Purcell, M. (2006). Avoiding the local trap: Scale and food systems in planning research. Journal of Planning Education and Research, 26(2), 195-207. http://dx.doi.org/10.1177/0739456X06291389
Brown, S., \& Getz, C. (2008). Privatizing farm worker justice: Regulating labor through voluntary certification and labeling. Geoforum, 39(3), 1184 1196. http://dx.doi.org/10.1016/j.geoforum.2007.01.002

Bryman, A. (2012). Social Research Methods. Oxford, UK: Oxford University Press.

Campbell, H. (2009). Breaking new ground in food regime theory: Corporate environmentalism, ecological feedbacks and the 'food from somewhere' regime? Agriculture and Human V alues, 26(4), 309-319. http://dx.doi.org/10.1007/s10460$\underline{009-9215-8}$

Chang, H.-J. (2009). Rethinking public policy in agriculture: Lessons from history, distant and recent. Journal of Peasant Studies, 36(3), 477-515. http://dx.doi.org/10.1080/03066150903142741

Chiffoleau, Y. (2009). From politics to co-operation: The dynamics of embeddedness in alternative food supply chains. Sociologia Ruralis, 49(3), 218-235. http://dx.doi.org/10.1111/j.1467-9523.2009. 00491.x

Conner, D., Becot, F., Hoffer, D., Kahler, E., Sawyer, S., \& Berlin, L. (2013). Measuring current consumption of locally grown foods in Vermont: Methods for baselines and targets. Journal of Agriculture, Food Systems, and Community Development, 3(3), 83-94. http://dx.doi.org/10.5304/jafscd.2013.033.004 
Cooksey, B. (2011). Marketing reform? The rise and fall of agricultural liberalisation in Tanzania. Development Policy Review, 29(S1), S57-S81. http://dx.doi.org/ 10.1111/j.1467-7679.2011.00520.x

Crush, J. S., \& Frayne, G. B. (2011). Urban food insecurity and the new international food security agenda. Development Southern Africa, 28(4), 527-544. http://dx.doi.org/10.1080/0376835X.2011.605571

DuPuis, E. M., \& Goodman, D. (2005). Should we go "home" to eat?: Toward a reflexive politics of localism. Journal of Rural Studies, 21(3), 359-371. http://dx.doi.org/10.1016/j.jrurstud.2005.05.011

Engler-Stringer, R. (2010). Food, cooking skills, and health: A literature review. Canadian Journal of Dietetic Practice and Research, 71(3), 141-145. http://dx.doi.org/10.3148/71.3.2010.141

Evans, N., Morris, C., \& Winter, M. (2002). Conceptualizing agriculture: A critique of postproductivism as the new orthodoxy. Progress in Human Geography, 26(3), 313-332. http://dx.doi.org/10.1191/0309132502ph372ra

Feenstra, G. (2002). Creating space for sustainable food systems: Lessons from the field. Agriculture and Human Values, 19(2), 99-106. http://dx.doi.org/10.1023/A:1016095421310

Food and Agriculture Organization of the United Nations (FAO). (2001). Food balance sheets: $A$ handbook. Rome: Author. Retrieved from http://www.fao.org/docrep/003/x9892e/ x9892e00.htm

FAO. (2011). The state of food insecurity in the world 2011: How does international price volatility affect domestic economies and food security? Rome: Author. Retrieved from http://www.fao.org/docrep/014/i2330e/ i2330e00.htm

FAO. (2013). Hunger Portal. Rome: Author. Retrieved from http://www.fao.org/hunger/en/

Friedmann, H. (2007). Scaling up: Bringing pubic institutions and food service corporations into the project for a local, sustainable food system in Ontario. Agriculture and Human Values, 24(3), 389398. http://dx.doi.org/10.1007/s10460-006-9040-2

Grivetti, L. E., \& Ogle, B. M. (2000). Value of traditional foods in meeting macro and micronutrient needs: the wild plant connection. Nutrition Research Reviews, 13(1), 31-46. http://dx.doi.org/10.1079/095442200108728990
Guthman, J. (2002). Commodified meanings, meaningful commodities: Re-thinking productionconsumption links through the organic system of provision. Sociologia Ruralis, 42(4), 295-311. http://dx.doi.org/10.1111/1467-9523.00218

Hadley, C., Linzer, D. A., Belachew, T., Mariam, A. G., Tessema, F., \& Lindstrom, D. (2011). Household capacities, vulnerabilities and food insecurity: Shifts in food insecurity in urban and rural Ethiopia during the 2008 food crisis. Social Science and Medicine, 73(10), 1534-1542.

http://dx.doi.org/10.1016/j.socscimed.2011.09.004

Hartmann, C., Dohle, S., \& Siegrist, M. (2013). Importance of cooking skills for balanced food choices. Appetite, 65(1), 125-131. http://dx.doi.org/10.1016/j.appet.2013.01.016

Headey, D. (2011). From drought to development in the Horn of Africa: How can we strengthen the evidence base? [Unpublished concept note]. Washington, D.C.: International Food Policy Research Institute (IFPRI) and the International Livestock Research Institute (ILRI).

Hinrichs, C. C. (2000). Embeddedness and local food systems: Notes on two types of direct agricultural market. Journal of Rural Studies, 16(3), 295-303. http://dx.doi.org/10.1016/S0743-0167(99)00063-7

Hinrichs, C. C. (2003). The practice and politics of food system localization. Journal of Rural Studies, 19(1), 33-45. http://dx.doi.org/10.1016/S0743-0167(02) 00040-2

Holloway \& Kneafsey, (2004). Producing-consuming food: Closeness, connectedness and rurality in four 'alternative' food networks. In: L. Holloway \& M. Kneafsey (Eds.), Geographies of rural cultures and societies (pp. 257-277). London: Ashgate.

Holloway, L., Kneafsey, M., Venn, L., Cox, R., Dowler, E., \& Tuomainen, H. (2007). Possible food economies: A methodological framework for exploring food production-consumption relationships. Sociologia Ruralis, 47(1), 1-19. http://dx.doi.org/ 10.1111/j.1467-9523.2007.00427.x

Hossain, N., \& Ebyen, R. (Eds.). (2009). Accounts of crisis: Poor people's experiences of the food, fuel and financial crises in five countries. London: Institute of Development Studies. Retrieved from http://www.ids.ac.uk/ 
Ilbery, B., \& Bowler, I. (1998). From agricultural productivism to post-productivism. In: B. Ilbery (Ed.), The geography of rural change (pp. 57-84). Harlow, UK: Longman.

Ilbery, B., \& Kneafsey, M. (2000). Producer constructions of quality in regional specialty food production: a case study from south west England. Journal of Rural Studies, 16(2), 217-230. http://dx.doi.org/10.1016/S0743-0167(99)00041-8

Ilbery B., Morris, C., Buller, H., Maye, D., \& Kneafsey, M. (2005). Product, process and place: An examination of food marketing and labelling schemes in Europe and North America. European Urban and Regional Studies, 12(2), 116-132. http://dx.doi.org/10.1177/0969776405048499

Inter-Agency Standing Committee (IASC) Task Force on Climate Change. (2009). Climate change, food insecurity and hunger: Key messages for UNFCCC negotiators. Geneva: Author. Retrieved from http://www.humanitarianinfo.org/iasc/download doc.aspx?docID $=5031 \&$ type $=$ pdf

Jaffe, D., \& Howard, P. H. (2010). Corporate cooptation of organic and fair trade standards. Journal of Agriculture and Human Values, 27(4), 387-399. http://dx.doi.org/10.1007/s10460-009-9231-8

Jarosz, L. (2008). The city in the country: Growing alternative food networks in metropolitan areas. Journal of Rural Studies, 24(3), 231-244. http://dx.doi.org/10.1016/j.jrurstud.2007.10.002

Knezevic, I., Landman, K., Blay-Palmer, A., \& Nelson, E. (Eds.). (2013). Models and best practices for building sustainable food systems in Ontario and beyond. Guelph, Ontario: Ontario Ministry of Agriculture, Food and Rural Affairs. Retrieved from http://nourishingontario.ca/models-andbest-practices

Legwegoh, A. F., \& Hovorka, A. J. (2013). Assessing food insecurity in Botswana: The case of Gaborone. Development in Practice, 23(3), 346-358. http://dx.doi.org/10.1080/09614524.2013.781128

Maxey, L. (2006). Can we sustain sustainable agriculture? Learning from small-scale producer-suppliers in Canada and the UK. The Geographical Journal, 172(3), 230-244. http://dx.doi.org/10.1111/j.14754959.2006.00211.x

McMichael, P. (2009). The world food crisis in historical perspective. Monthly Review, 61(3), 32-47. Retrieved from http://monthlyreview.org/
Miele, M. (2006). Consumption culture: The case of food. In P. Cloke, T. Marsden, \& P. Mooney (Eds.), The Handbook of Rural Studies (pp. 344-354). London: Sage. http://dx.doi.org/10.4135/9781848608016.n24

Milestad, R., Bartel-Kratochvil, R., Leitner, H., \& Axmann, P. (2010). Being close: The quality of social relationships in a local organic cereal and bread network in Lower Austria. Journal of Rural Studies, 26(3), 228-240. http://dx.doi.org/10.1016/i.jrurstud.2010.01.004

Morris, C., \& Kirwan, J. (2011). Exploring the ecological dimensions of producer strategies in alternative food networks in the UK. Sociologia Ruralis, 51(4), 349-369. http://dx.doi.org/10.1111/j.14679523.2011.00546.x

Moseley, W. G., Carney J., \& Becker, J. (2010). Neoliberal policy, rural livelihoods, and urban food security in West Africa: A comparative study of The Gambia, Cote d'Ivoire, and Mali. Proceedings of the National Academy of Sciences, 107(13), 5774-5779. http://dx.doi.org/10.1073/pnas.0905717107

Mount, P. (2012). Growing local food: Scale and local food systems governance. Agriculture and Human Values, 29(1), 107-121. http://dx.doi.org/10.1007/s10460-011-9331-0

Naylor, R. L., Falcon, W. P., Goodman, R. M., Jahn, M. M., Sengooba, T., Tefera, H., \& Nelson, R. J. (2004). Biotechnology in the developing world: A case for increased investments in orphan crops. Food Policy, 29(1), 15-44. http://dx.doi.org/10.1016/i.foodpol.2004.01.002

Ohberg, L. A. (2012). What's stopping us? Identifying barriers to the local food movement using Ontario, Canada as a case study. Toronto: University of Toronto. Retrieved from http://hdl.handle.net/1807/33482

Oluoko-Odingo, A. A. (2011). Vulnerability and adaptation to food insecurity and poverty in Kenya. Annals of the Association of American Geographers 101(1), $1-20$. http://dx.doi.org/10.1080/00045608.2010.532739

Ostrom, M. (2009). Everyday meanings of "local food": Views from home and field. Community Development, 37(1), 65-78. http://dx.doi.org/10.1080/15575330609490155 
Peters, C. J., Bills, N. L., Lembo, A. J., Wilkins, J. L., \& Fick, G. W. (2009). Mapping potential foodsheds in New York State: A spatial model for evaluating the capacity to localize food production. Renewable Agriculture and Food Systems, 24(1), 72-84. http://dx.doi.org/10.1017/S1742170508002457

Qazi, J. A., \& Selfa, T. L. (2005). The politics of building alternative agro-food networks in the belly of agroindustry. Food, Culture and Society 8(1),45-72. http://dx.doi.org/10.2752/155280105778055416

Renting, H., Marsden, T. K., \& Banks, J. (2003). Understanding alternative food networks: Exploring the role of short food supply chains in rural development. Environment and Planning A, 35(3), 393-411. http://dx.doi.org/10.1068/a3510

Rosset, P. (2008). Food sovereignty and the contemporary food crisis. Development, 51(4), 460463. http://dx.doi.org/10.1057/dev.2008.48

Sage, C. (2003). Social embeddedness and relations of regard: Alternative "good food" networks in southwest Ireland. Journal of Rural Studies, 19(1), 47-60. http://dx.doi.org/10.1016/S0743-0167(02)00044$\underline{X}$

Shapiro, L. (2004). Something from the oven: Reinventing dinner in 1950s America. New York: Viking.

Smithers, J., \& Joseph, A. E. (2010). The trouble with authenticity: Separating ideology from practice at the farmers' market. Agriculture and Human Values, 27(2), 239-247. http://dx.doi.org/10.1007/s10460009-9250-5

Smithers, J., Lamarche, J., \& Joseph, A. E. (2008). Unpacking the terms of engagement with local food at the Farmers' Market: Insights from Ontario. Journal of Rural Studies, 24(3), 337-350. http://dx.doi.org/10.1016/j.jrurstud.2007.12.009

Sneyd, L. Q., Legwegoh, A., \& Fraser, E. D. G. (2013). Food riots: Media perspectives on the causes of food protest in Africa. Food Security, 5(4), 485-497. http://dx.doi.org/10.1007/s12571-013-0272-x

Sonnino, R., \& Marsden, T. (2006). Beyond the divide: Rethinking relationships between alternative and conventional food networks in Europe. Journal of Economic Geography, 6(2), 181-199. http://dx.doi.org/10.1093/jeg/lbi006

Stitt, S. (1996). An international perspective on food and cooking skills in education. British Food Journal,
98(10), 27-34.

http://dx.doi.org/10.1108/00070709610153795

Stock, P., \& Carolan, M. (2012). A Utopian perspective on global food security. In C. Rosin, P. Stock, \& H. Campbell (Eds.), Food systems failure: The global food crisis and the future of agriculture (pp. 114-127). New York: Earthscan.

Swan, S. H., Hadley, S., \& Cichon, B. (2010). Crisis behind closed doors: Global food crisis and local hunger. Journal of Agrarian Change, 10(1), 107-118. http://dx.doi.org/10.1111/j.1471-0366.2009. 00252.x

Timmer, C. P. (2010). Reflections on food crises past. Food Policy, 35(1), 1-11. http://dx.doi.org/10.1016/i.foodpol.2009.09.002

Venn, L., Kneafsey, M., Holloway, L., Cox, R., Dowler, E., \& Tuomainen, H. (2006). Researching European 'alternative' food networks: Some methodological considerations. Area, 38(3), 248258. http://dx.doi.org/10.1111/j.1475-4762.2006. 00694.x

Watts, D. C. H., Ilbery, B., \& Maye, D. (2005). Making reconnections in agro-food geography: Alternative systems of food provision. Progress in Human Geography, 29(1), 22-40. http://dx.doi.org/10.1191/0309132505ph526oa

Weis, T. (2007). The global food economy: The battle for the future of farming. Black Point, Nova Scotia: Fernwood Publishing.

Weis, T. (2011). The perilous dependence on cheap food imports and a different path forward (TNI Discussion paper). Amsterdam: Transnational Institute. Retrieved from http://www.tni.org/article/perilousdependence-cheap-food-imports-food-security

Wittman, H. K., Desmarais, A. A., \& Wiebe, N. (Eds.). (2010). Food sovereignty: Reconnecting food, nature and community. Black Point, Nova Scotia: Fernwood Publishing.

Wrieden, W. L., Anderson, A. S., Longbottom, P. J., Valentine, K., Stead, M., Caraher, M., ... Dowler, E. (2007). The impact of a community-based food skills intervention on cooking confidence, food preparation methods and dietary choices-An exploratory trial. Public Health Nutrition, 10(2), 203211. http://dx.doi.org/10.1017/S1368980007 $\underline{246658}$ 